\title{
Organic olive farming in Andalusia, Spain. A review
}

\author{
Carmen Rocío Rodríguez Pleguezuelo ${ }^{1}$. Víctor Hugo Durán Zuazo ${ }^{2}$ - José Ramón Francia Martínez ${ }^{1}$. \\ Francisco José Martín Peinado ${ }^{3}$. Francisco Moreno Martín ${ }^{4}$ • Iván Francisco García Tejero ${ }^{2}$
}

Accepted: 13 March 2018 / Published online: 5 April 2018

(C) INRA and Springer-Verlag France SAS, part of Springer Nature 2018

\begin{abstract}
Olive is a key crop in the Mediterranean basin, socially, economically, and environmentally, being a major source of rural employment. Organic products such as olive oil have attracted many types of consumers in recent years. In this context, the Mediterranean basin represents 5 Mha of the 10 Mha of olive farming worldwide, with Spain being the leading producer. Also, during the recent decades, olive farmers met the challenges of sustainability by implementing principles of agroecological production. Therefore, the focal point is no longer exclusively on yields but also on the quality, health, and environmental aspects of products and systems. In this work, we review and analyse the global situation of organic farming, focusing on the development, current status, perspectives, and opportunities of organic olive farming in Andalusia (S Spain). In addition, we assess the environmental benefits and consequences of the shift from conventional to organic management of olive orchards, focusing on the improvement of soil quality and biodiversity. Also, the general factors affecting the decision making for acquiring organic olive oil are discussed. Our main findings show the following: (1) It is necessary to encourage educational and research programmes to promote the demand for these products, positively affecting consumer health, protecting the environment, and improving rural economies. (2) The future of organic agriculture will depend on its economic viability and on the determination shown by governments to protect these practices. (3) Further support for funding research is needed to continue studying the effect of olive cultivation on soil biological quality, changes in soil properties, and biodiversity. More importantly, these beneficial extra outputs produced for society must be interiorised in economic value to compensate organic oil producers. (4) Finally, a clear understanding of attitudes and preferences, as well as the motivations of consumer when making the choice for organic olive products, is essential in responding to this specific demand. However, as stated above, major institutional and educational actions are also needed in order to boost sustainable organic olive farming and thus the preference for organic olive oil.
\end{abstract}

Keywords Andalusia $\cdot$ Olive organic farming $\cdot$ Environmental impact $\cdot$ Conventional systems

Víctor Hugo Durán Zuazo

victorh.duran@juntadeandalucia.es

1 IFAPA Centro "Camino de Purchil”, Apdo. 2027, 18080 Granada, Spain

2 IFAPA Centro "Las Torres-Tomejil”, Ctra. Sevilla-Cazalla, Km 12.2. 41200-Alcalá del Río, Sevilla, Spain

3 Departamento de Edafología y Química Agrícola, Universidad de Granada, C/Severo Ochoa s/n, 18071 Granada, Spain

4 Excmo. Ayuntamiento de la Malahá, Concejalía de Medio Ambiente, Calle Real 16, 18130 Granada, Spain

\section{Contents}

1. Introduction

2. Growth of the European organic farming sector 2.1. Spanish organic farming

\subsubsection{Andalusian olive sector}

3. Environmental impacts of shifting from conventional to organic olive farming

3.1. Agricultural soils

3.2. Soil biodiversity

4. Organic olive multi-functionality

5. Factors affecting the development of organic olive farming Acknowledgements

References 


\section{Introduction}

The application of organic agriculture results in less leaching of nutrients and higher carbon storage, lower erosion rates, and lower levels of pesticides in water bodies (Reganold et al. 1987; Kreuger et al. 1999; Mäder et al. 2002). In this holistic approach, the farm is seen as part of nature, a selfcontained system that keeps external inputs to a minimum (FAO 2014). Additionally, organic farming strongly relies on closed on-farm nutrient cycling for "closing the loop", including biological nitrogen fixation or crop rotation to enhance soil fertility by protecting soil organic-matter content (Leifeld 2012). Thus, this agricultural management system protects biodiversity, biological cycles, and natural soil activity and keeps off-farm inputs to a minimum while supporting techniques that conserve ecological equilibrium (Gold 2014).

On the other hand, techniques from intensive agriculture have led to the depletion of forests and grasslands over the past decades. In fact, it is predicted that during the coming years, agricultural expansion will significantly impact global biodiversity (Bienvenuti and Bretzel 2017). For instance, these artificial systems are directly related to the decline in bird populations on European farmland (Donald et al. 2001) and to the loss of invertebrate taxa (Preston et al. 2002). Additionally, Hole et al. (2005) in relation to the comparison between conventional and organic systems stated that a wide range of taxa, from different groups such as birds, mammals, invertebrates, and arable flora, decreases in abundance and/or species richness in intensive agriculture.

Nevertheless, many sectors contrary to organic agriculture base their arguments on the lower crop yields. According to FAO (2014), the performance of organic agriculture on production depends on the previous agricultural management system. Hence, in industrial countries, organic systems generally produce lower yield, by an amount which depends on the intensity of external inputs previously used. However, in irrigated lands, organic agriculture usually leads to almost identical production levels. Moreover, in many traditional rain-fed agricultural areas (with low external inputs), organic agriculture has proved to be able to increase yields.

In the EU, since the beginning of the 1990s, considerable efforts have been made to promote and develop organic agriculture. To achieve this, EU countries have provided financial assistance for organic producers such as conversion subsidies for compensating the lower incomes earned during the beginning of conversion (EC 2017).

In this context, the expansion of the cultivation of olive (Olea europaea L.) trees in the Mediterranean basin is clearly the paradigm for the increased specialisation throughout southern European countries in recent decades (Fig. 1). The territorial impact of olive cultivation in southern Spain is in fact of high importance, since it has an extremely high level of land occupation and it is the leading olive oil producer and exporter of the world. In 2015, the production for olive growing was 7,352,095 t, with an efficiency ranging from 2270 to $5356 \mathrm{~kg} \mathrm{ha}^{-1}$ for rain-fed and irrigated plantations, respectively (Anuario de Estadística 2016). Olive is indeed in some provinces such as Jaén and Córdoba an extreme case of monoculture with over $91 \%$ of land occupied by olive trees, making it one of the highest concentrations of tree crops in the entire EU (Sánchez and Paniza 2015). Likewise, organic olive oil production has considerably increased worldwide (FIBL and IFOAM 2016), but everything is not advantageous, as organic agriculture also has several drawbacks that should be taken into account, such as expensive certification systems or few organic inputs available in some places, making the final price of the organic products generally higher. Nevertheless, this price increase is often justified, due to the higher production costs for organic foods because of greater labour inputs per unit of output and the expensive control systems to avoid fraud. Also, the production can be uneven, and therefore the harvest and distribution costs are greater than those for conventional foods.

In this work, we review and discuss the global situation of organic farming, focusing on the development, current situation, perspectives, and opportunities of organic olive farming in Andalusia (S Spain). In addition, we analyse the environmental benefits and consequences of the shift from conventional to organic management of olive orchards, focusing on the improvement of soil quality and biodiversity. Also, the general factors that govern the decision making for acquiring organic olive oil are discussed.

\section{Growth of the European organic farming sector}

By Regulation (EC) No 834/2007 (EC 2007), the European Council of Agricultural Ministers established an organic regulation on the production and labelling of organic products. This policy defined objectives, principles, and general rules for organic production and replaced Regulation (EEC) 2092/91. The results of these policies were as expected: the surface area of organic agricultural land has vastly increased, each year, with 500,000 ha of agricultural land being converted to organic in the EU. For 2000-2012, the total organic area increased by $6.7 \%$ yearly, to reach 9.6 million ha, which is $5.4 \%$ of the total agricultural area used in the EU (COM 2014).

In 2012-2013, the Commission reviewed the European policy on organic agriculture by the Action Plan on the Future of Organic Production in Europe (COM 2014). The plan anticipates providing farmers better information on rural development and EU farm-policy initiatives, encouraging organic farming, reinforcing links between organic farming and EU research and innovation, and to foment the use of organic 


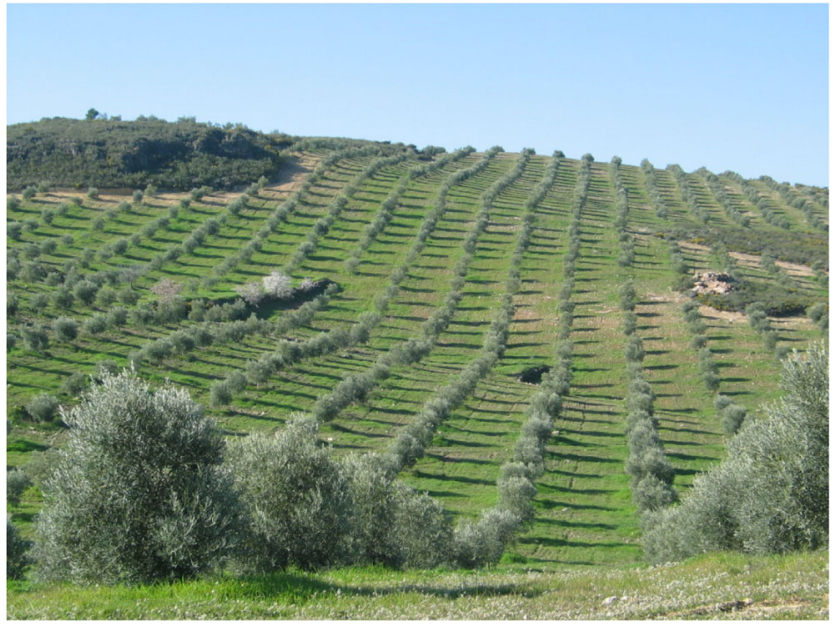

Fig. 1 Organic olive groves in Andalusia (S Spain)

food in public places such as schools and hospital. Additionally, the Rural Development Plan for (2014-2020) foresees a separate measure to recognise the importance of organic farming for the contribution of many rural development priorities and support both conversion and maintenance of organic farming.

Concomitantly, the number of farms has expanded from fewer than 20,000 in 1991 (Organic Farming in Europe 2012) to 340,000 producers in 2014 (EC 2013), the bulk of this surge occurred mainly in just a few countries: Spain, France, Germany, and Poland. According to EUROSTAT 2015, Austria is the member state where the weight of the organic sector in the total utilised agricultural area (UAA) was the highest in 2015 (20.3\%), followed by Sweden and Estonia (with 17.1 and $15.7 \%$, respectively). In this context, it is also important to point out that Spain is the seventh state member with respect to the share of total agricultural area occupied by organic farming, with $8.2 \%$, and it is the first country for total area devoted to organic farming $(1,410,500$ ha in 2015). All of the EU 15 member states have undergone increases in the percentage of total utilised agricultural area from 1999 to 2015, ranging from 2.9\% for Denmark to $300.1 \%$ for Spain, the latter registering the highest jump in the percentage of agricultural area put into use.

According to the most recent data, for 2014, there were around 340,000 producers of organic agricultural products, the value of the European organic market being 26.2 billion $€$, with an annual growth of $7.6 \%$ in 2014. It is important to point out that the new CAP 2014-2020 supports are provided by means of Pillar 1 (direct payments) and Pillar 2 (Rural Development Programmes (RDPs)). In this sense, certified organic farmers are qualified for receiving the so-called Greening payments. The application of these new measures started in 2015 with a great part of EU Member States proffering organic area payments for conversion to and maintenance of organic management under the Common
Agricultural Policy Rural Development Programmes (FIBL and IFOAM 2016). As of the end of 2015, all 118 RDPs had been adopted. Current European Commission data predict that over 10 million ha of land will be supported by the new Rural Development Programmes. The organic area payments will represent about $6.4 \%$ of EU public expenses for Rural Development Programmes to 2020 (FIBL and IFOAM 2016). During 2017, Member States will also have the possibility of moving up to $15 \%$ of their Pillar 1 budget to Pillar 2 for the years 2018 and 2019. Therefore, these projections suggest that more ambitious efforts could still be made by the Member States to stimulate the growth of organic food and farming.

\subsection{Spanish organic farming and oil consumption}

The rise of organic agriculture has been more appreciable in Spain, currently being the European country with the highest organic agriculture surface area, i.e. 1,410,500 ha, and a total of 34,673 producers in 2015 . The sales of organic products in Spain have risen by $5.42 \%$ during the period 2011-2013, with a total volume of 1018 million $€$ (Ecological 2016). The spending per capita has also increased from $20.45 €$ to 21.66 $€$. Despite these low values, the annual expense in organic products in Spain increased by $8.3 \%$ from 2009 to 2012 (MAGRAMA 2013a), although still far from the growth in other countries such as that in France, Italy, Austria, Germany, or Denmark, which grew by 4 to $10 \%$.

In this line, the year 2012 can be considered a consolidation period of the wide support infrastructure for the Spanish organic production. Despite the slight decrease in surface area cultivated, the production of most of the plant products increased. Products such as oil, citrus fruits, legumes, dried fruits, subtropical fruits, and industrial crops have noticeably increased their production (MAGRAMA 2013a).

The number of organic operators in Spain surpassed 33,600 in 2014 and the number of producers underwent a modest increment of $0.46 \%$ from 30,462 to 30,602 for the period 2012-2014. On the other hand, the organic preparers or transformers have also shown a notable rise of $9.4 \%$ from 2790 to 3082 that can be explained by the expanding trend of the local market and the exportation of prepared and transformed products (MAPAMA 2014). The highest growth rate in 2012 was registered in the organic industry, which increased in $20.12 \%$ of establishments. In total, 4127 industries were registered, of which 3361 were related to vegetable production and 766 with animal production (MAGRAMA 2013b), with a continuous yearly growth during the period 1991-2010.

Regarding the motivation of the Spanish consumer for choosing organic products, a recent study by the Organic Monitor (Ecological 2016) reported that the consumption of organic products in Spain was approximately $21 €$ per person per year, which is still very low compared with that of 
Switzerland (210€), Denmark (163€), or Luxemburg (157€). According to MAPAMA (2014), the average organic consumer is well informed and, furthermore, the percentage of those who consume organic products everyday has increased.

Therefore, the Spanish consumer is increasingly more aware of the influence of diet on health and at the same time this is motivating the search for more natural products, bringing with it certain other new consumption tendencies related to organic farming such as "Bio-products without gluten", the so-called super-foods, and the vegan dietary tendency.

According to a recent report of the Italian farmers' group Coldiretti (2016), global consumption of olive oil has almost doubled over the last 25 years with a jump of $73 \%$ (Fig. 2). World olive oil consumption in 2015 was 3,295,911 t. Italy led the list of consumers with $640,443 \mathrm{t}$, followed by Spain with $540,133 \mathrm{t}$ and the USA, which consumed 339,512 tons, for a $250 \%$ increase over 25 years ago (Coldiretti 2016). Also, in Japan, the consumption in 2015 was 66,139 t, which represented a $1400 \%$ increase over the 25 -year period, while the UK and Germany each consumed around 65,000 t, for an increase of 763 and $465 \%$, respectively. Another example is Russia, where the growth was threefold in 25 years to about 23,149 t, and in France consumption exceeded 113,538 t, representing an increase of 268\% (Coldiretti 2016).

Furthermore, Spain is currently the largest European olive oil producer, accounting for more than one third of global production (Montes et al. 2013) and increasing on average by 1 to $1.5 \%$ per year from 1995 to the present (ESYRCE 2015).

\subsubsection{Andalusian olive sector}

In this context, during recent decades, especially after Spain's accession to the European Union in 1986, the olive sector underwent remarkable expansion (Gómez and Riesgo 2012). This expansion was reflected in an increase in the area devoted to olive orchards and the intensification through both higher density planting and the introduction of irrigation. In Spain, the olive growing surface area is 2.61 million ha, of which 1.57 million ha (60\%) are in Andalusia (S Spain), increasing on average by $1-1.5 \%$ per year from 1995 to the present (ESYRCE 2015). Subsidies and the rising price of olive oil have fostered this growth (Parras and Lozano 2014). The average olive oil production over the last six seasons with available data (2010/11-2015/16) has been 1,757,700 t, this production being 1,661,000 $\mathrm{t}$ for 2015/2016 (MAPAMA 2016). It is also important to highlight that during the last decade the average production has risen $23 \%$ compared to that of the previous period, which was 986,654 t (MAPAMA 2016). The Andalusia olive sector has undergone a powerful shift in rural development, as the organic olive has undergone a considerable increment in area devoted to its organic cultivation, mainly due to the demand for organic olive oil.
In this line, of the 2.5 million ha of Spanish olive orchards, 688,245 ha is registered by the 28 Protected Designations of Origin (PDO) for olive oil existing in Spain, and most of them are in Andalusia (Erraach et al. 2014). The food-quality certification under PDO is established by EU regulation and ensures some quality requirements that are higher than those of other food products. Foods covered by PDOs have quality and characteristics that are due to the geographical environment, with its natural or anthropogenic components. Their production and processing always take place in the delimited geographical area that gives them their name.

Along this line, according to MAGRAMA (2015), of the total of $1,968,570.38$ ha of organic agriculture in Spain in 2015, 1,011,076.27 ha was in Andalusia, of which $28,772.34$ ha was in conversion and 707,103.47 ha was already certified, followed by the regions Castilla-la-Mancha, Catalonia, and Extremadura. In Andalusia (southern Spain), there are currently 1.5 million ha under olive orchard cultivation, representing about $40 \%$ of the useful agricultural area. This accounts for $80 \%$ of Spanish production and one third of the olive orchards in Europe. In this context, the surface area of organic olive crops in Andalusia have considerably expanded in the last few years, from 31,851 ha in 2001 to $54,800.68$ ha in 2012 , thus making up $3.6 \%$ of total olive orchards in Andalusia (Aforo de Olivar 2013).

The main factor influencing this expansion is the ease of converting the traditional olive orchards into organic olive orchards, the campaigns to help control the olive fly [Bactroceraoleae (Rossi) (Diptera: Tephritidae)], the European economic support, and the development of scientific and technical knowledge. Cordoba is the province with the greatest amount of organic olive orchards, with 26,924.46 ha in 2015 , followed by Sevilla with $18,104.75$ ha and Jaén with 9380.81 ha. However, the percentage of organic olive orchards in the total organic surface area in Andalusia has been reduced in the last few years, due to a lack of adequate organic olive mills (Bosa 2011). In fact, some olive mills do not differentiate between organic and conventional olives, so the final product has the same label regardless of the origin, and the work of farmers is not properly recognized.

In Andalusia, the regional government has recently published the " 3 rd Andalusian Plan of Organic Production Horizon 2020" to support and expand the organic agriculture and industry. This current plan has the following objectives: (1) to consolidate the growth of the Andalusia organic sector, the model or example being on the national and European level; (2) to strengthen the economic and environmental competitiveness of organic plantations and industry; (3) to increase public knowledge referring to the consumption pattern and preferences of organic products; (4) to analyse the trends of organic products in the distribution chains and to improve this commercialisation in the local, national, and international market; (5) to promote the consumption of organic food; and 


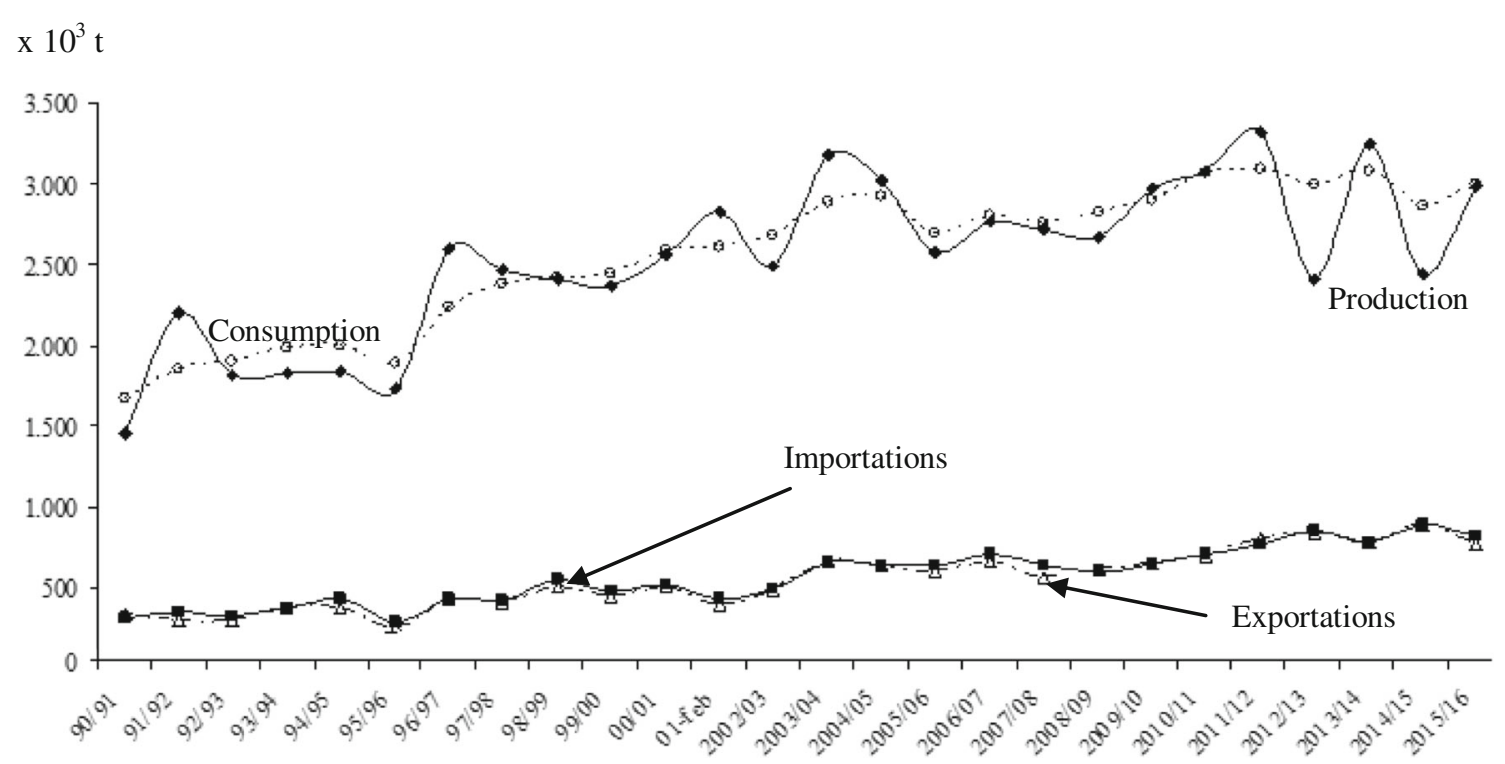

Fig. 2 Global production, consumption, exportation, and importation of olive oil (Coldiretti 2016)

(6) to reinforce the trust in the consumption of these products. To achieve these objectives will require the organisation and structuring of the organic production sector, the promotion and boosting of consumption, and improvement in marketing organic products.

Moreover, according to the data, the production of organic olive oil in Andalusia is predicted to increase in the coming years, which will also raise the number of agricultural day workers. However, even with these positive perspectives, it is still necessary to encourage the concentration of the offer and establish commercial practices that promote a better balance in the value chain of organic olive oil.

The consideration of organic olives and organic olive oil as a "strategic sector" in Andalusia is due to its potential to spur the economy and generate employment, and also because of its social, environmental, and cultural value. Besides considering this sector as an income and job promoter, it must also be interpreted as a sector which satisfies an environmental necessity, of land management, social equilibrium, and promotion of familiar enterprises, thereby promoting the new functions that society demands from the rural environment and fostering the sustainable agriculture in olive-growing areas.

\section{Environmental impact of shifting from conventional to organic olive farming}

\subsection{Agricultural soils}

Semi-arid Mediterranean climate regions are among the most productive agricultural areas worldwide (Aznar et al. 2011). Despite their high productivity, many of the agricultural soils in these areas have very low organic matter content and are exposed to severe degradation and persistent fertility loss. Semi-arid soils are exposed to erosion by infrequent but intense precipitation, absence of plant cover, and high organic matter mineralisation rates related to high temperatures (Durán and Rodriguez 2008; Maestre et al. 2012).

In this context, the expansion and intensification of olive orchards has caused negative environmental impacts such as soil erosion, overexploitation of water resources, biodiversity losses, groundwater pollution, and damage to traditional agricultural landscapes (Guzmán 2005; Francia et al. 2006; Durán et al. 2009; Sánchez et al. 2015). Moreover, soils in the Mediterranean area are very sensitive to soil management practices. This is more important even in this zone, where desertification is a major environmental problem. In fact, under the prevailing semi-arid climatic conditions of Andalusia, intensive tillage in olive farming promotes soil organic depletion and nutrient losses; furthermore, tillage increases $\mathrm{CO}_{2}$ emission, thus contributing to global climate change. Therefore, it is of urgent need to search for solutions and alternatives to preserve soil organic matter. Factors affecting this include soil properties and the climate itself (Lal 2009), but also soil management is a crucial factor (Vicente et al. 2016).

Conventional soil management has been used since ancient times to reduce water competition between trees and weeds in Spanish Mediterranean olive orchards (Fernández et al. 2016), and the benefits for soil properties under organic management systems in olive plantations (Soriano et al. 2013).

Recently, Parras and Lozano (2014) under organic farming management in olive orchards for a 20 -year monitoring period determined the benefits of increasing the soil organic carbon stocks in relation to conventional tillage system. With respect to the mitigation of $\mathrm{CO}_{2}$ emission, some of the advantages of woody crops in general are biomass accumulation, promoting 
net carbon sequestration when herbaceous crops are replaced by fruit orchards. Furthermore, fruit orchards produce pruning debris that may be utilised for animal feeding or for producing energy, among other purposes (Infante and González 2013). However, there is some concern about the temporal limitation of soil carbon sequestration, which would take place only until a new situation of equilibrium arrives (González et al. 2012).

In this context, Aguilera et al. (2015) analysed the greenhouse gas contribution of 42 pairs of organic and conventional perennial cropping systems in Andalusia, using life cycle assessment, reporting that the olive systems registered the highest difference in carbon footprint between conventional and organic management. That is, the carbon footprint averaged 24 and $-10 \mathrm{~g} \mathrm{CO}_{2}$ per $\mathrm{kg}$ for conventional and organic systems, respectively. Additionally, they demonstrated that conventional olive orchards have high emissions related to fertiliser production and, conversely, high carbon sequestration in organic management.

Thus, organic olive systems are in line with the climatic change mitigation strategy, since this management is directly related to measures such as cover cropping and recycling pruning debris. In addition, it is well known that deeper soil horizons can sequester higher quantities of organic carbon (Lorenz and Lal 2005). In this context, Parras et al. (2013) studied the soil organic carbon, nitrogen stocks, C:N ratio and their stratification ratios for olive orchard soils, comparing organic farming and conventional tillage in "Los Pedroches" valley (Córdoba province, Andalusia). They found higher $\mathrm{C}$ and $\mathrm{N}$ concentrations in organic olive systems. Moreover, soil property stratification in depth, expressed as a ratio, indicates the soil quality under different soil management systems. The soil stratification for carbon ranged from 2.2 to 3.1 in organic farming and from 2.1 to 2.2 in conventional tillage. However, only SR 2 (defined by these authors as Ap-A/C) showed significant differences between conventional tillage and organic farming. This soil stratification ratio for $\mathrm{N}$ showed similar trends.

Consequently, organic olive farming reduces or eliminates tillage and uses organic matter (such as manure or compost) to avoid chemical fertilisers. This decreases $\mathrm{CO}_{2}$ soil emissions and is part of the recommended sustainable agriculture that should be of public and global interest. This is a conclusion shared by many studies which have demonstrated that organic olive systems promote higher contents of soil organic matter and nitrogen when compared to conventional olive crops. One of the reasons may be due to the use of organic amendments and the establishment of cover crops in sloping lands of Andalusia (Soriano et al. 2013; Francia et al. 2006; Durán et al. 2009, 2016). This has been shown in a significant way in some studies (Castro et al. 2008; Pajares et al. 2011), but in some other cases these changes have not been so evident (Mäder et al. 2002). Likewise, in a recent study, Calabrese et al. (2015) investigated whether organic farming techniques can promote plant biodiversity and soil quality in old Mediterranean olive orchards and defined several indicators for evaluating the effectiveness. They concluded that among the organic orchards tested, differences were significant in the establishment for the different grass covers used, and a positive influence of organic management techniques was monitored on soil quality parameters and biodiversity. In orchards located in Andalusia, Sánchez et al. (2015) reported the impact of soil management systems on nematode biodiversity, soil physical and chemical parameters, and soil food webs.

Additionally, for sustainable soil use management, patterns in $\mathrm{N}$ soil fertilisation might have a great effect on $\mathrm{N}$ dynamics that must be monitored to make fertilisation programmes sustainable. In line with this, Gómez et al. (2015) evaluated net N mineralisation and nitrification in organic and conventional olive orchards of two locations differing in $\mathrm{N}$ input. In all cases, net $\mathrm{N}$ mineralisation and nitrification were higher in soils under the tree canopy. Additionally, both parameters were higher in organic farming than in conventionally managed orchards in the location with high soil total $\mathrm{N}$. They also reported that annual soil $\mathrm{N}$ availability in olive orchards in all types of management proved higher than or similar to tree demand. Therefore, the calculation of the optimum $\mathrm{N}$ supply must be addressed in order to develop sustainable $\mathrm{N}$ fertilisation programmes.

Álvarez et al. (2007) compared soil properties in organic olive orchards and neighbouring natural zones in Andalusia. Two soil types (Eutric Regosol and Eutric Cambisol) and the most common soil management methods (tillage and two intensities of grazing) were studied. In general, they found lower values of organic carbon, macro-aggregate stability, bulk density, and saturated hydraulic conductivity in the tilled systems compared with those in the grazed ones. $\mathrm{K}$ and $\mathrm{N}$ soil concentrations were at an adequate level in the olive systems but $\mathrm{P}$ was too low. Organic olive systems had good properties and there were almost no significant differences with natural areas (Álvarez et al. 2007). In agreement with this, we conclude that in general organic olive orchards improve soil properties over the long term.

\subsection{Soil biodiversity}

Olive management also directly affects soil microbial activity and biodiversity. In this context, García et al. (2009) compared soil enzymes, nematode communities, and physical-chemical soil properties in three pairs of organic and conventional olive systems in Andalusia. Also, they monitored several nematode community indicators. The utilisation of the different systems explained a maximum of 26.3 and $15 \%$ of the variability found for soil enzymes and nematode community indicators, respectively. They found that organic olive-growing systems had higher soil enzyme activities. Regarding nematode 
indicators, the organic olive systems registered higher values only for one of the study areas. The geometric mean of enzyme activities was higher in organic than that in conventional olive orchards. Also, the greater biodiversity in Andalusian olive orchards under organic management has also been demonstrated by using breeding birds as indicators of sustainability. As an example, Solomou and Sfougaris (2014) demonstrated higher alpha diversity in organic and abandoned olive orchards and maquis than in conventional systems. They also found the highest beta diversity between the following pairs: organic olive orchards-maquis and abandoned olive orchards-maquis. Breeding-bird diversity as well as Heteroptera, Hymenoptera, Hemiptera, and Coleoptera densities positively influenced bird species richness in organic olive orchards and maquis. However, these authors found that bird species diversity was affected negatively by the use of pesticide and inorganic fertiliser application in conventional olive orchards.

Following in this context of biodiversity, Cárdenas et al. (2015) evaluated how management in olive orchards affects spiders, which are considered the natural enemies of orchard pests. They studied 18 olive orchards in Andalusia and included both ground-dwelling and canopy spider species. It was found that the organic system had a significantly higher level of abundance and diversity of canopy spiders than did the integrated pest management and conventional systems. Agricultural techniques such as ploughing had a negative impact on spider abundance and diversity whereas the establishment of hedge vegetation benefitted spiders. It is suggested that sustainability (in terms of pest control) in olive-orchard agroecosystems may be attained by maintaining hedge vegetation regardless of the management system. In these terms, also Glisakis et al. (2016) monitored soil arthropods for 2 years in organic, conventional, and integrated olive orchards in Greece. They evaluated farming practices, climate, and landscape complexity, and found significant differences in arthropod community between agroecological zones for specific taxa, seasonal diversity indexes, and functional subgroups. The group of climate, farming practices, and landscape factors consistently explained a larger portion of arthropod variability, than did management systems and agroecological zones together. These authors concluded that temperature and soil tillage, as well as relative humidity, were the most important explanatory variables.

Additionally, nematode assemblages are used as bioindicators of soil conditions in several agroecosystems. They have several features that make them appropriate for their use as bioindicators: ubiquity, abundance, and diversity. These change quickly in response to external changes (Yeates and Bongers 1999) and can be used as bioindicators of various soil functions due to the numerous roles that nematodes play within the soil food web. In this context, Sánchez et al. (2015) reported that nematode abundance and soil food webs were reduced by herbicide use in comparison to nearby oak woodlands: nematode abundance by $47.7 \%$, taxon richness by $12.4 \%$, and soil food web structure by $23.4 \%$.

In addition, organic management has recently been demonstrated to be more efficient than conventional biological control for the olive fruit fly (Bactroceraoleae). Picchi et al. (2017) estimated the effect of predators on overwintering pupae sentinels. They found that in organic orchards, exposed pupae were more consumed than were pupae in conventional orchards. However, they also concluded that further experiments are necessary to clarify the role of semi-natural habitats in supporting ground pest control and support natural solutions as alternatives to the pesticide strategy.

Furthermore, biodiversity itself should have a monetary value to achieve this preservation. One of the conditions to determine this may be its quantification. The extinction or fragmentation of the original natural landscape in Andalusia is currently critical due to the extension of the land devoted to olive. Arthropod fauna is one of the most sensitive groups to these land-use changes, its monitoring in olive orchards being a good alternative to discriminate between types of management as part of the so-called bioindication, which is a powerful tool to overcome the state of the biodiversity in an agroecosystem (Ruano et al. 2004). In Andalusia, Jerez et al. (2014) recently evaluated arthropod fauna to distinguish between olive-management types (organic, conventional with non-tillage, and conventional with tillage). They stated that organic olives had higher abundance, diversity, and richness of orders, concluding that the use of the arthropod community has proven to be efficient to differentiate between organic and non-organic orchards.

On the other hand, bioindicators are also used by monitoring enzyme activity and microbial carbon assimilation, these being good indicators for evaluating the quality and state of a soil (Bastida et al. 2012). In this sense, Montes et al. (2013) determined the effect of the practices of organic and conventional olive orchards in Andalusia on chemical and biological parameters by using biological assay and enzymatic activities Their results clearly discriminated three types of soils according to the management system (conventional, organic, or wild olives). Furthermore, organic olive orchards had higher contents of soil organic matter, organic $\mathrm{C}, \mathrm{N}$, and $\mathrm{C}: \mathrm{N}$ ratio and higher microbial diversity compared to conventionally managed orchards.

With regard to soil management, but with reference to global environmental issues, Mohamad et al. (2013) studied the effects of agricultural practices comparing organic and traditional olive orchards in Italy on global warming potential by using the approach of the life cycle. They determined that there was a higher environmental impact on global warming potential in organic orchards due to the higher use of manure fertilisation rather than the synthetic foliar fertilisers utilised in conventional systems. At the same time, 
manure was the reason of higher soil organic carbon and $\mathrm{C}$ sequestration in organic systems. Consequently, they found higher efficiency of $\mathrm{C}$ sequestration in the soil following the addition of soil organic matter. The contribution of the manure to increased soil organic matter compensated for the higher carbon emission in the organic olive orchards, resulting in higher negative net $\mathrm{C}$ flux in the organic vs. the conventional system.

With respect to weed biodiversity, Lisek and Sas (2015) studied segetal and ruderal weeds in organic orchards with woody fruit trees. In these organic systems, weeds under canopy are eliminated with a rototiller, and in conventional systems with post-emergence herbicides, with the result that the total number of weed species in each organic orchard was higher than in the conventional version, as a result of the soil management. The biodiversity in an orchard depends on several factors, such as weed control techniques, environmental conditions, crop rotation, and type of the neighbouring crops or the proximity to natural habitats (Hole et al. 2005; Lisek and Sas 2015). However, no studies are available comparing weed diversity in organic and conventional olive orchards.

Thus, traditional olive-orchard soil management systems based on the use on herbicides and leaving the bare soil negatively affect soil biodiversity, as well as soil properties, as was reported by the aforementioned studies. As a result, organic olive farming stands as a viable option to conserve soil properties and biodiversity with opportunities to increase sustainable agroenvironmental measures.

\section{Organic olive multi-functionality}

The progression of the term "ecosystem services" within policy strategies has promoted many definitions of this concept. According to the UK Department of Environment, Food, and Rural Affairs (DEFRA 2007), ecosystem services can be described as providing the following: (i) natural resources for basic survival; (ii) a contribution to good physical and mental health (green spaces, genetic resources for medicines); (iii) natural processes (climate regulation); (iv) support for economy (raw material for industry, agriculture or tourism); (v) social, cultural, and educational benefits.

The Millennium Ecosystem Assessment is among the most important projects to investigate the concept of ecosystem services (MEA 2005). That is, there are three categories when defining specific ecosystem services: (i) provisioning services (food, fresh water, fibre, etc.); (ii) regulating services (climate regulation, disease regulation, pollination, etc.); and (iii) cultural services (recreation and tourism, educational, sense of place, etc.).

In this context, one of the ecosystem services (ESs) of orchards is the capacity to sequester atmospheric $\mathrm{CO}_{2}$, usually called the net ecosystem production, which is the balance between the amount of organic $\mathrm{C}$ fixed by photosynthesis (gross primary production and the respiration) (Chapin et al. 2006). In particular, values of net ecosystem production vary from 760 to $1250 \mathrm{~g} \mathrm{C} \mathrm{m}^{-2} \mathrm{y}^{-1}$ in irrigated olive orchard (Nardino et al. 2013). Also, the protection of soil with cover crops in organic farming orchards has a positive effect in controlling soil erosion on the one hand by intercepting rainfall and protecting the soil surface against the impact of raindrops, and on the other hand by reducing runoff. Moreover, vegetation and litter increase soil aggregate stability and water infiltration (Durán and Rodriguez 2008).

Additionally, it bears pointing out that ecosystem services exist because people are beneficiaries of those services (Montarano et al. 2017). In rural areas, soil is a key social resource since it is related to employment in a number of farm and farm-related jobs. Olive tree cultivation plays an important socioeconomic role by providing different ESs which includes food, local jobs, and the maintenance of traditional skills (Mohamad et al. 2013). Many landscapes from Southern Europe are formed and shaped up by the traditional techniques and customs (van Berkel and Verburg 2014). In some areas, these olive landscapes are unique elements related to the history and culture of the area and they are an important attraction for tourism (Ottomano et al. 2016). An example of tourism as an ecosystem service related to olive culture is the so-called oleotourism (Millán et al. 2015). These latter authors analysed this type of activity as an alternative to economic diversification in several municipalities of Andalusia. Oleotourism attracts visitors to the olive area for an in-depth immersion in the oil culture (Millán et al. 2015): visits to oil mills, old oil windmills, oleo-libraries and specialized shops or museums, olive farms, and the olive landscapes (there are also some monumental tree specimens), participating in oil celebrations, oil-tasting festivals, itineraries related to qualified designation-of-origin oils, or attendance to major trade exhibitions, etc.

Other less tangible types of ecosystem services include cultural services, which are related to aesthetic, recreational, and spiritual benefits. This group may include ecotourism, and the use of cultural heritage (Daniel et al. 2012). The main problem of this group is the intangibility of these benefits, which makes it difficult to measure or even establish a methodology to address them: human health or well-being, enjoyment of natural daylight or fresh air of rural areas. In fact, despite the reduction of the traditional olive systems, the natural values associated with olive growing in Andalusia have resulted in the maintenance up to the present of a considerable number of ecosystems of natural interest, including 138, 536 ha of olive (approximately $10 \%$ of the total olive surface area) under different forms of legal protection included in Natura 2000 Net. 
In this context, in Andalusia, Parra et al. (2005) used an analytic hierarchy process (AHP) to assess the multifunctionality of three olive management systems (conventional, organic, and integrated) by considering criteria of different types: economic, technical, socio-cultural, and environmental. These authors concluded that in the specific application of AHP to olive, there is a general agreement among experts on the feasibility of organic olive system compared to integrated and conventional. Both organic and integrated systems are overall better, since they have a higher value for the society as a whole over the medium and long term, because they conserve soil, water, and genetic resources, they protect the environment, and their techniques are economically viable and more socially accepted. In this line, Carmona et al. (2014) evaluated a new methodology to assess multifunctionality by a farm-level model for olive growing in Andalusia. Using the Analytic Network Process (ANP), which is a Multi-Criteria Decision Analysis method, they reported that olive growers are already shifting to optimal alternative strategies to achieve high-quality products but they are disregarding social and environmental impacts. They also found that the economic improvement is compatible with social objectives and with environmental protection.

In the same sense, by taking into account several factors (economic, environmental, and socio-cultural), Egea and Pérez (2016) analysed the sustainability of some Spanish olive oil Protected Designations of Origin (PDO) through multicriteria techniques by studying different olive management systems. These authors made this analysis through 10 criteria grouped into three clusters: economic, environmental, and socio-cultural and asked experts, concluding that organic farming is the best system, followed by integrated farming, when achieving economic, environmental, and socio-cultural criteria. Conventional farming was in the third position when achieving all functions, except for the environmental criteria, for which abandonment is preferred to conventional farming in all PDOs. These authors stated that improved sustainability of rural areas is encouraged at the European level, by paying farmers for externalities.

In contrast to forest ecosystems, which are known for their ability to sequester $\mathrm{C}$ or regulate the water cycle (García et al. 2013), the concept of ecosystem service has not been widely used in orchard research in general. The reason appears to be that in orchards the focus is on the production of consumable food, whereas the multi-functionality of wood-producing forests, which is close to the ecosystem service concept, has long been recognized. However, orchards have several features that might make them important for ecosystem service studies. For example, the perennial character of trees, the multi-stratum habitat, and the plant diversity within the boundaries of orchards contribute to a high level of biodiversity. The potential of $\mathrm{C}$ sequestration by orchard soils could be reassessed and increased to mitigate climate change.
Thus, we conclude that the internalisation of positive outputs and benefits of organic olive production is of crucial importance for society. In fact, we propose that only by orientating institutional policies to an adequate provision of ecosystem services will it be possible to make this internalisation socially efficient. To achieve this, we must take into account the concept of "agrarian multi-functionality", which was first used by the EU at the end of the 1990s and covers the following functions: (i) agrarian production, (ii) the preservation of rural areas and landscapes, and (iii) the contribution to the social feasibility of rural areas.

Furthermore, studying and analysing ecosystem services should be the base to support public decision-making priorities and to design policies for agricultural strategies, because only by reorienting these strategies could public intervention be economically and socially efficient.

\section{Factors affecting the development of organic olive farming}

Studies related to the nutrient content of organic foods have demonstrated higher concentrations of vitamins, carotenoids, unsaturated fatty acids, and polyphenols (Palupi et al. 2012). In this context, Jiménez et al. (2014) studied the physicochemical characteristics and nutritional quality of virgin olive oils from two very common varieties in Andalusia (Picual and Hojiblanca) at different ripening stages, grown using organic or conventional methods. They found significant differences in the acidity, oxidative stability, tocopherol contents, fatty acid composition, and phenol contents of oils from organically and conventionally cultivated olives. However, the variety and the ripening stage had a stronger effect on the physicochemical and nutritional parameters than did management (organic or conventional). Therefore, due to the increasing demand for these types of products and environmental protection, further research is needed to analyse the effect of organic cultivation on the olive oil quality.

Additionally, the average European consumer places more value on "organic" olive oil than on conventional (Kalogeras et al. 2009). However, in Spain, the impact and importance of the organic market are not very high compared with those in other countries (Vega-Zamora et al. 2013). A search for the reason implies ascertaining the reasons why the average consumer of organic olive oil buys this product. In Spain, the reason for this decision is usually health related, for food safety, and taste (Gracia and Magistris 2008; Vega-Zamora et al. 2013). However, the idea of expanding organically cultivated products was originally based on preserving the environment and promoting rural economic development. In this line, some studies have related these values with the decision of purchase (e.g. Honkanen et al. 2006), but in general most studies conclude that the decision is more personal and selfish and not 
based on environmental benefits. In fact, it is necessary to question the consumers directly as to whether they buy organic olive oil also to benefit the environment (Vega-Zamora 2013).

Additionally, when a consumer is questioned for the superiority of organic foods compared to conventional, characteristics such as healthfulness, quality, or taste are not always so clear (Brennan et al. 2003). Although some previous studies have related environmental protection to a preference for organic foods (Kriwy and Mecking 2012), most ascribe less importance to the environment than to health as a purchase motivator. In the same context, other studies have related the lack of knowledge of the consumer with the low consumption of organic products (MAGRAMA 2007), which constitutes an obstacle for the expansion of such products, including olive oil.

On the other hand, the two main reasons why consumers do not choose organic olive oil in Spain is the high cost and the limited availability, together with generalized unawareness and confusion (Vega-Zamora 2013; Ecological 2016). Nor do Spanish consumers perceive important differences between organic and conventional olive oil, since they already very much appreciate the extra-virgin olive from conventional management, and, already being satisfied, consequently are not willing to pay the extra charge of organic oil. According to Vega-Zamora (2013), it is crucial to undertake awarenessraising campaigns to boost the knowledge of consumers about organic olive, and it is also necessary to differentiate it clearly from the conventional oil, emphasising its differences in relation to health and taste. Additionally, it is necessary to make organic olive oil more accessible in the common shopping sites, this requiring more extensive distribution. In this line, the private sector, producers, and intermediate agents must actively take part in this process by supporting the public administration.

In this same context of difficulties, organic farmers are frequently at a certain disadvantage compared with conventional ones. One of the reasons may be that conventional olive agriculture depends less heavily on land, as they use great amounts of energy and nutrients from fossil and mineral sources (Guzmán et al. 2011). The concept of sustainability in agriculture involves a land cost that should be included as an external cost and given monetary value. In this context, Guzmán et al. (2011) developed this concept by applying it to organic farming, estimating that the land cost of agrarian sustainability for establishing the comparison between organic olive and conventional olives in orchards in Andalusia. These authors have shown that agroenvironmental subsidy is not enough to induce the olive farmer to switch to organic farming because the land cost of this new system is not sufficiently offset. It was also shown that encouraging the multifunctionality of the land could reduce these extra costs. Encouraging the change to organic olive cultivation in
Andalusia could be achieved by promoting the creation of alperujo composting plants, the maintenance of hedges, and the use of biofuels in agricultural machinery, according to Guzmán et al. (2011).

In general terms, Table 1 presents an analysis of the strengths, weaknesses, opportunities, and threats (SWOT) for the Spanish organic olive production and trade. It is important to point out that despite the economic crisis and a complex and unfavourable context, the interior trade of organic products has slightly increased (in amount and value), this being an important sign of the great potential of growth of organic farming in Spain.

One threat for Spanish olive oil production is that several other Mediterranean countries are improving their final oil product and making it more competitive. Facing this situation, Andalusia should promote the products of organic agriculture in which it can be more competitive, encouraging a strong and differentiated image of quality. Moreover, with the incorporation of a higher number of consumers in the EU market, there is a growing potential market for Andalusia products. Additionally, organic Andalusian agriculture already has commercial channels of exportation for some products such as olive oil. In this context, international export would not be difficult for the organic version of these products, resulting from promoted diversification and differentiation by quality.

Smallholders are still more vulnerable to these problems when they are not part of any organisation. However, according to "Plan Andaluz 2007-2013", productive diversification is still a disregarded problem. In this sense, the design of the public funding sometimes generates difficulties for small farmers: lack of information to process the applications, complicated compliance of the minimum in surface area when having diverse and varied crops, and disadvantages when compared with farmers linked to agroindustries (sometimes also subsidised). In addition, obstacles in the productive and commercial chain are other problems for organic production in Andalusia. For example, adequate supplies are lacking or deficient, such as seeds, phytosanitary products, manures, fodders for livestock, and the commercial distribution channels. Therefore, it is of high priority to invest in research and education programmes, to make progress in this promising sector. Organic farming is a strategic investment linked to the environmental protection but, furthermore, these activities might attract young people towards rural areas, which are currently affected by depopulation, and help solve the ageing problem of rural areas in Andalusia (Molinero and Rodríguez 2012).

On the other hand, in Andalusia, large stores and hypermarkets price organic products comparatively higher than analogous conventional products, fomenting the wrong perception of exclusivity to consumers. However, the sale of organic products in small and medium stores could generate in the consumer an impression of confidence based on the image of proximity and familiarity with these shops. In this context, 
Table 1 Strengths, weaknesses, opportunities, and threats (SWOT) analysis of organic farming in Andalusia, Spain
Strengths

- This sector has undergone an enormous surge in production and demand

- There are activities of formation and research in the sector

- Favourable climatic conditions and proper conditions for olive cultivation exist

- The sector has a reliable control system and it is generally accepted

- Possibilities of producing high-quality and highly demanded items

- There is a stable consumer group of organic products

- New opportunities exist for self-employment and attracting the young population to rural areas

\section{Opportunities}

- The European Commission and other public organisations support organic agriculture

- The European normative framework is increasingly restrictive over time on environmental aspects

- The consumer is more concerned about food security

- The demand from European countries is increasing considerably

- Andalusia has optimal agricultural and environmental conditions to develop the organic agriculture

- Traditional agricultural techniques are still in use with potential to shift to organic agriculture

- Andalusian agroindustry is quite large and dynamic
Weakness

- There is strong dependence on public funding

- A considerable part of producers are small and medium-sized farmers

- The production is widely scattered throughout Andalusia

- Frequently, there are difficulties in finding affordable effective inputs (pesticides, herbicides, etc.)

- Farmers and technicians tend to have low educational training and background

- Research focusing on agroecology remains insufficient

- The transfer of research findings to agricultural sector is deficient

- Few enterprises are working on preparing, transforming, and selling organic products

- Possible misunderstandings arise in the identification of products by the consumer, because of a plethora of labels

- The required conversion periods are long

Threats

- Part of the increase in this sector is due to public funding rather than due to increasing demand

- Competition is increasing in the European market and other "third countries", with different policies and lower production costs

- Other controlled agriculture types are emerging

- Society is not properly informed about organic systems

- Possible confusion arises concerning similar terms such as artisanal, natural products, and origin denomination

- The European public funding might be reduced in the near future some studies have analysed the willingness to pay in different countries. Gil et al. (2000) estimated this in different segments of customers in Spain for organic products. For this purpose, these researchers considered a wide range of food products such as vegetables, potatoes, cereals, fruits, eggs, chicken, and red meat. Consumers in two regions (Madrid and Navarra) were analysed. Their results indicated that consumers who were worried about a healthy diet and environmental problems were the most likely to buy organic food, and were willing to pay a high extra cost.

A similar study was carried out by Espejel and Fandos (2008) in Aragón (Spain), who analysed the relation between the perceived qualities of a protected designation of origin of olive as a determining factor of the purchase intention. They demonstrated that the quality measured by intrinsic attributes is the only motivation to buy for the consumer (colour, flavour, shape, and appearance in the market). However, attributes such as place of origin or the image of a traditional product do not exert an important influence. These authors found that the reason is probably the short time that the protected designation of origin of olive oil has been in force.

Likewise, Bernabéu and Díaz (2016) studied the preferences of olive oil consumers and to propose business strategies for the production sector. They concluded that consumers prefer low-priced oil, extra virgin, and organic. The appearance of the bottle was not relevant in the decision making when buying olive oil, although it could be a factor in expanding the market share (Bernabéu and Díaz 2016). Currently, according to these authors, there are two consumer segments: $67.1 \%$ of them based their buying decision on price while $32.9 \%$ were guided by the product's specific attributes, including organic production.

Thus, this indicates that it is important to improve and invest in innovation, since this may be the key for the 
competitiveness of organic olive oil. Diversification is a good opportunity for positioning organic products in the demanding global market. Additionally, growing concern of the consumer in relation to safety and healthiness of the products and respect for the environment has promoted the imposition of new requirements on the food industry. Thus, the promotion of organic olive oil for the public and private sector should be of high priority.

\subsection{Decision-making factors for the consolidation of organic olive farming}

The development and promotion of organic olive farming will depend of the general perception of the Spanish and European consumer (Fig. 3). As mentioned above, factors affecting the decision of when to buy organic olive oil remain unclear. Some authors have pointed out that the main motivation is the oil's region of origin (Delgado and Guinard 2011), but this is true mainly for experienced, local, or family consumers, while this factor does not affect urban or less experienced consumers (Caporale et al. 2006). Other reasons include the health benefits of organic olive oil and, of course, flavour. Thus, organic olive oil should be promoted as beneficial for health and consequently advertising strategies and policy measures should be based on these claims.

According to our results, we recommend educational and research programmes to encourage the demand of these products, positively affecting consumer health, protecting the environment, and improving rural economies. However, the future of organic agriculture will depend on its economic viability and on the determination shown by governments to protect these practices. Further support for funding research is needed to continue studying the effect of olive cultivation on soil biological quality, changes in soil properties, and biodiversity. More importantly, these beneficial extra outputs produced for society must be interiorised in the economic value to compensate organic oil producers.

Furthermore, for organic olive farming in Andalusia to be a feasible alternative to conventional farming, the extra costs need to be offset by the national and regional governments (Fig. 3), since the market is unable to do so at present. An

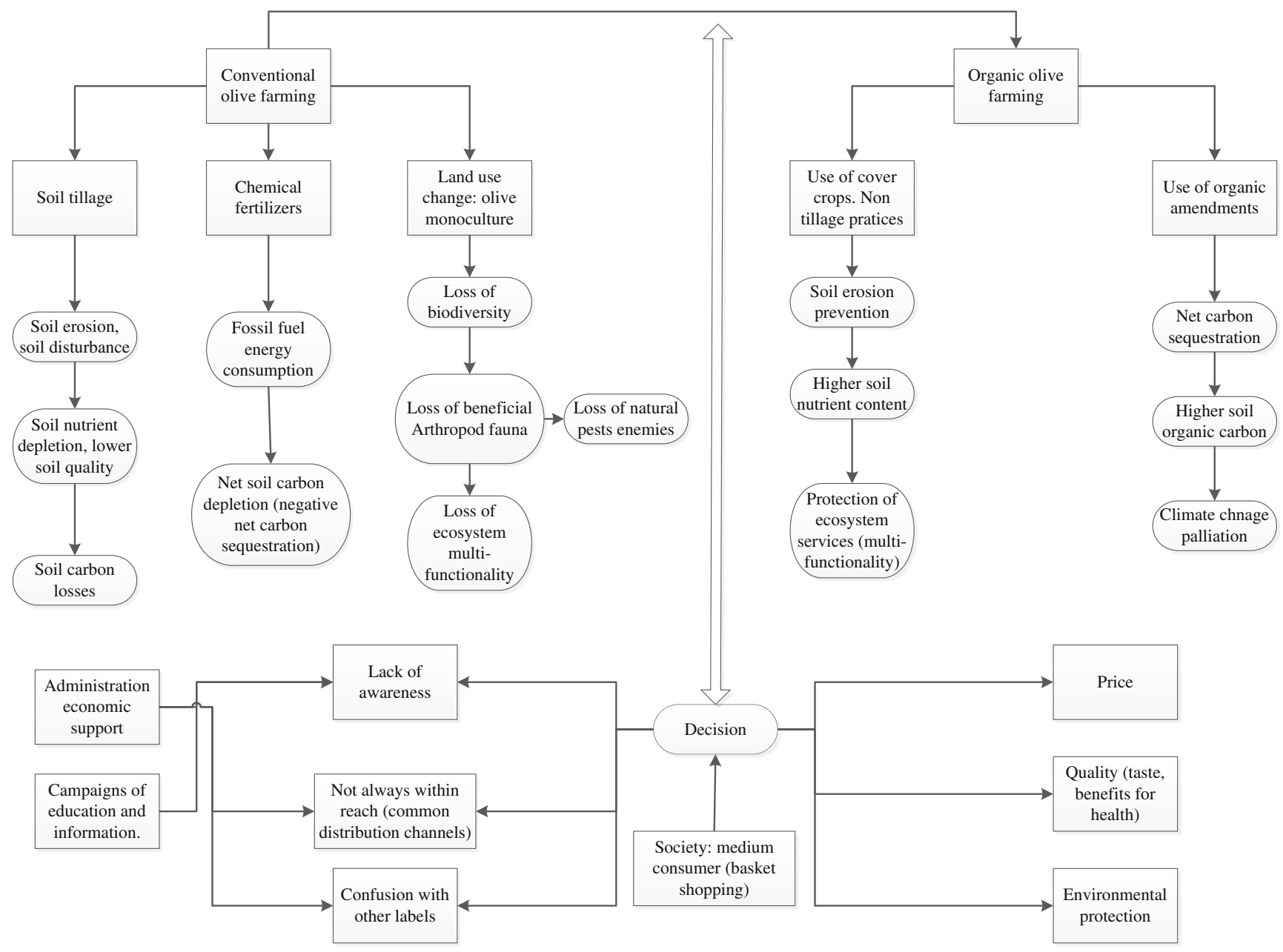

Fig. 3 Decision-maker consumer factors in relation to environmental impacts and benefits for conventional vs. organic farming 
innovative solution for the near future to compensate for these costs may be to take into account the "Payments for Environmental Services" scheme. Currently, there is a hot topic relating to the financial assessment of these services, to give monetary value to such services and how this might be done.

From this review, we can summarise the following strengths and future perspectives:

(i) High future growth of the global market in organic products:

- Continuous growth of the overall surface are dedicated to organic agriculture (more than 38 million ha)

- Inclusion of new producer countries in the market

- New zones, crops, and investments in this sector

- Growth in consumption of big new markets

- Increase in the international trade of organic products

- Growth in concern about health habits, food, and environment

- Innovation and expansion of types of organic products

- Growth in e-commerce in organic products

(ii) Future trends in organic olive production in Andalusia:

- Andalusia has a large cultivated surface area and a mature structure of production

- It has a prestigious certification structure

- The local consumption is still limited but with high potential

- The distribution by means of short channels represents a good opportunity to reduce the cost for production

- International consumers in demanding organic products are predicted to increase in the coming decades

- The organic production could be an alternative or differentiation to certain sectors such as olive sector

- Organic production is predicted to generate employment

We conclude that the economic support incentives for the promotion of organic products, which are limited to a higher price tag for its products, are not sufficient. Government strategies designed to promote organic olive cultivation should compensate by funding the higher land cost that organic farmers have, to increase the sustainability of their crops. This is of high priority because organic olive farmers are unable in some cases to compete with conventional ones because of the costs they have in order to reach the same production level. This is why the EU Common Agricultural Policy compensates organic farming with agroenvironmental funds. However, these measures may not be sufficient in the context of a Mediterranean climate.
In this context, the consumer has the final decision about how much money can be allocated to promote organic production and to choose which products they may support. Awareness-raising campaigns are crucial to enrich the knowledge of consumers concerning organic olive oil and differentiating it clearly from the conventional, emphasising its differences in healthfulness and flavour. The introduction of organic oil in the common commercial areas where the average consumer normally shops is also necessary, not only in the large shopping malls. The first and main step to achieve a higher assessment and consumption of organic olive oil should be an extensive programme of education and transfer, from primary schools to university levels, but also including hotels, the catering sector, and public services (e.g. hospitals and schools). Authorities and consumers need to join in this transformation towards more sustainable Andalusian olive farming, given the vital importance in protecting and conserving agricultural soil. Commercial olive orchards under organic management may promote and conserve soil quality and health, and the future of organic olive orchards will depend largely on consumer demand. Consequently, it is necessary to develop a consumeroriented approach to understand how to shift in terms of market dynamics. A clear understanding of consumer attitudes and preferences and the motivations of consumer when making the choice for organic olive products is necessary to meet this specific demand.

Acknowledgements This publication was sponsored by the following research project "Agro-environmental assessment of conventional, integrated, conservation and organic olive production systems in mountainous areas: impact on erosion, soil quality and commercial value of olive oil" (P11 AGR-7431) granted by CEC of Junta de Andalucía.

\section{References}

Aforo de Olivar campaña (2013) Consejería de Agricultura, Pesca y Medio Ambiente, Junta de Andalucía

Aguilera E, Guzmán G, Alonso A (2015) Greenhouse gas emissions from conventional and organic cropping systems in Spain. II. Fruit tree orchards. Agron Sustain Dev 35:725-737. https://doi.org/10.1007/ s13593-014-0265-y

Álvarez S, Soriano MA, Landa BB, Gomez JA (2007) Soil properties in olive groves compared with that in natural areas in a mountainous landscape in southern Spain. Soil Use Manag 23:404-416. https:// doi.org/10.1111/j.1475-2743.2007.00104.x

Anuario de Estadística (2016) Avance 2016. Ministerio de Agricultura y Pesca, Alimentación y Medio Ambiente, Madrid

Aznar SJA, Galdeano GE, Pérez MJC (2011) Intensive horticulture in Almería (Spain): a counterpoint to current European rural policy strategies. J Agrar Chang 11:241-261. https://doi.org/10.1111/j. 1471-0366.2011.00301.x

Bastida F, Jindo K, Moreno JL, Hernández T, García C (2012) Effects of organic amendments on soil carbon fractions, enzyme activity and 
humus enzyme complexes under semi-arid conditions. Eur J Soil Biol 53:94-102. https://doi.org/10.1016/j.ejsobi.2012.09.003

Bernabéu R, Díaz M (2016) Preference for olive oil consumption in the Spanish local market. Spanish J Agric Res 14:1-11. https://doi.org/ 10.5424/sjar/2016144-10200

Bienvenuti S, Bretzel F (2017) Agro-biodiversity using windflowers: what is the appropriate weed management for their long-term sustainability? Ecol Eng 102:519-526. https://doi.org/10.1016/j. ecoleng.2017.02.062

Bosa MS (2011) La agricultura ecológica como parte de la estrategia de desarrollo rural sostenible en Andalucía. Centro de Estudios Andaluces, Consejería de la Presidencia, Sevilla

Brennan C, Gallagher K, McEachern M (2003) A review of the consumer interest in organic meat. Int J Consum Stud 27:381-394. https://doi. org/10.1046/j.1470-6431.2003.00307.x

Calabrese G, Perrino EV, Ladisa G, Aly A, Tesfmichael SM, Mazdaric S, Benedetti A, Ceglie FG (2015) Short-term effects of different soil management practices on biodiversity and soil quality of Mediterranean ancient olive orchards. Org Agric 5:209-223. https://doi.org/10.1007/s13165-015-0120-8

Caporale G, Policastro S, Carlucci A, Monteleone E (2006) Consumer expectations for sensory properties in virgin olive oils. Food Qual Prefer 17:116-125. https://doi.org/10.1016/j.foodqual.2005.07.011

Cárdenas M, Pascual F, Campos M, Pekár S (2015) The spider assemblage of olive groves under three management systems. Environ Entomol 44:509-518. https://doi.org/10.1093/ee/nvv030

Carmona TC, Parra LC, Hinojosa RA, Sayadi S (2014) Farm-level multifunctionality associated with farming techniques in olive growing: an integrated modelling approach. Agric Syst 127:97-114. https://doi.org/10.1016/j.agsy.2014.02.001

Castro J, Fernández OE, Rodríguez PCR, Lallena AM, Sierra M, Aguilar $J$ (2008) Effects of different olive-grove management systems on the organic carbon and nitrogen content of the soil in Jaen (Spain). Soil Tillage Res 98:56-67. https://doi.org/10.1016/j.still.2007.10.002

Chapin FS, Woodwell GM, Randerson JT, Rastetter EB, Lovett GM, Baldocchi DD, Clark DA, Harmon ME, Schimel DS, Valentini R, Wirth C, Aber JD, Cole JJ, Goulden ML, Harden JW, Heimann M, Howarth RW, Matson PA, McGuire AD, Melillo JM, Mooney HA, Neff JC, Houghton RA, Pace ML, Ryan MG, Running SW, Sala OE, Schlesinger WH, Schulze ED (2006) Reconciling carbon-cycle concepts, terminology, and methods. Ecosystems 9:1041-1050. https://doi.org/10.1007/s10021-005-0105-7

Coldiretti (2016) ForzaAmica del Pese. Consumi: olio oliva conquista mondo, $+73 \%$ in una sola generazione. http://www.coldiretti.it/ news/Pagine/143-26-Febbraio-2016.aspx. Accessed 21 June 2017

COM (2014) Communication from the commission to the European Parliament, the council, the European economic and social committee and the committee of the regions. 179 final. Action Plan for the future of Organic Production in the European Union

Daniel TC, Muhar A, Arnberger A, Aznar O, Boyd JW, Chan KMA, Costanza R, Elmqvist T, Flint CG, Gobster PH, Grêt-Regamey A, Lave R, Muhar S, Penker M, Ribe RG, Schauppenlehner T, Sikor T, Soloviy I, Spierenburg M, Taczanowska K, Tam J, von der Dunk A (2012) Contributions of cultural services to the ES agenda. PNAS 109(23):8812-8819. https://doi.org/10.1073/pnas.1114773109

DEFRA (2007) An introductory guide to valuing ecosystem services. London, Crown Copyright. https://www.gov.uk/government/ uploads/system/uploads/attachment_data/file/181882/pb12852eco-valuing.pdf. Accessed 29 April 2017

Delgado C, Guinard JX (2011) Sensory properties of Californian and imported extra virgin olive oils. Food Sci 76:5170-5176. https:// doi.org/10.1111/j.1750-3841.2011.02040.x

Donald PF, Green RE, Heath MF (2001) Agricultural intensification and the collapse of Europe's farmland bird populations. Proc R Soc London Ser B Biol Sci 268:25-29. https://doi.org/10.1098/rspb. 2000.1325
Durán ZVH, Rodriguez PCR (2008) Soil erosion and runoff prevention by plant covers. A review. Agron Sustain Dev 25:65-86. https://doi. org/10.1051/agro:2007062

Durán ZVH, Rodríguez PCR, Martínez RA, Francia MJR, Cárceles RB (2009) Measures against soil erosion in rainfed olive orchards on slopes (SE Spain): impact of plant strips on soil-water dynamics. Pedosphere 4:453-464. https://doi.org/10.1016/S1002-0160(09) 60138-7

Durán ZVH, Rodríguez PCR, Cárceles RB, Pérez MJD, Francia MJR, Cuadros TS, García TI (2016) Plant strips as a sustainable strategy in reducing soil erosion in rainfed-tree crops. In: Teuter J (ed) Cover crops: cultivation, management and benefits. Nova Science Publishers, pp. 73-102

EC (2007) Council Regulation (EC) No 834/2007 of 28 June 2007 on organic production and labelling of organic products and repealing Regulation (EEC) No 2092/91. https://eur-lex.europa.eu/ legalcontent/EN/TXT/?uri=CELEX\%3A32007R0834. Accessed 27 March 2018

EC (2013) Facts and figures on organic agriculture in the European Union. Agriculture and Rural Development. https://ec.europa.eu/ agriculture/sites/agriculture/files/markets-and-prices/more-reports/ pdf/organic-2013 en.pdf. Accessed 21 July 2017

EC (2017) EU funding under the new CAP. Agriculture and rural development. Organic Farming. https:/ec.europa.eu/agriculture/organic/ eu-funding/eu-funding-and-the-new-cap_en. Accessed 27 July 2017

Ecological (2016) http://pae.gencat.cat/web/.content/al_alimentacio/ a101_pae/05_publicacions_material_referencia/arxius/2016 Informe_EcoLogical.pdf. Accessed 23 November 2016

Egea P, Pérez PL (2016) Sustainability and multifunctionality of protected designations of origin of olive oil in Spain. Land Use Policy 58:264-275. https://doi.org/10.1016/j.landusepol.2016.07. 017

Erraach Y, Sayadi S, Gomez A, Lopez C (2014) Consumer-stated preferences towards Protected Designation of Origin (PDO) labels in a traditional olive-oil-producing country: the case of Spain. New Mediterr 4:11-19

Espejel BJ, Fandos HC (2008) La calidad percibida como antecedente de la intención de compra del aceite de oliva del bajo Aragón con denominación de origen protegida. EsicMarket 131:253-227 http://www.esic.edu/documentos/revistas/esicmk/080912_113551_ E.pdf. Accessed 20 July 2017

ESYRCE (2015) Encuesta sobre superficies y rendimientos de cultivos. Ministerio de Agricultura, Alimentación y Medio Ambiente. Madrid

FAO (2014) Organic agriculture. http://www.fao.org/organicag/oa-faq/ oa-faq7/en. Accessed 14 November 2016

Fernández RML, Parras AL, Lozano GB, Clark JM, Collins SD (2016) Soil quality assessment based on carbon stratification index in different olive grove management practices in Mediterranean areas. Catena 137:449-458. https://doi.org/10.1016/j.catena.2015.10.019

FIBL and IFOAM (2016) The world of organic agriculture. Statistics and emerging trends 2016. https://shop.fibl.org/fileadmin/documents/ shop/1698-organic-world-2016.pdf. Accessed 16 December 2016

Francia JR, Durán ZVH, Martínez A (2006) Environmental impact from mountainous olive orchards under different soil-management systems (SE Spain). Sci Total Environ 358:46-60. https://doi.org/10. 1016/j.scitotenv.2005.05.036

García RR, Ochoa V, Viñegla B, Hinojosa MB, Peña SR, Liébanas G, Linares JC, Carreira JA (2009) Soil enzymes, nematode community and selected physico-chemical properties as soil quality indicators in organic and conventional olive oil farming: influence of seasonality and site features. Appl Soil Ecol 41:305-314. https://doi.org/10. 1016/j.apsoil.2008.12.004

García NA, García LM, Iniesta AI, Martín LB (2013) Mapping forest ecosystem services: from providing units to beneficiaries. Ecosys Serv 4:126-138. https://doi.org/10.1016/j.ecoser.2013.03.003 
Gil JM, Gracia A, Sanchez M (2000) Market segmentation and willingness to pay for organic products in Spain. Int Food Agribusiness 3: 207-226. https://doi.org/10.1016/S1096-7508(01)00040-4

Glisakis V, Volakakis N, Kollaros D, Bàrberi P, Kabourakis EM (2016) Soil arthropod community in the olive agroecosystem: determined by environment and farming practices in different management systems and agroecological zones. Agric Ecosyst Environ 218:178189. https://doi.org/10.1016/j.agee.2015.11.026

Gold M (2014) What is organic production? National Agricultural Library. USDA

Gómez LJA, Riesgo L (2012) Sustainability assessment of olive grove in Andalusia: a methodological proposal. New Medit-A Mediterranean Journal of Economics, Agric Environ 2:39-49

Gómez MB, Hinojosa MB, García RR (2015) In situ net mineralisation and nitrification under organic and conventionally managed olive orchards. Nutr Cycl Agroecosyst 101:223-239. https://doi.org/10. 1007/s10705-015-9672-y

González SEJ, Ordoñez FR, Carbonell BR, Veroz GO, Gil RJA (2012) Meta-analysis on atmospheric carbon capture in Spain through the use of conservation agriculture. Soil Tillage Res 122:52-60. https:// doi.org/10.1016/j.still.2012.03.001

Gracia A, Magistris T (2008) The demand for organic foods in the south of Italy: a discrete choice model. Food Policy 3:386-396. https://doi. org/10.1016/j.foodpol.2007.12.002

Guzmán AJR (2005) Territorio y medio ambiente en el olivar andaluz. Consejería de Agricultura y Pesca, Junta de Andalucía, España

Guzmán GI, González MM, Alonso AM (2011) The land cost of agrarian sustainability. An assessment. Land Use Policy 28:825-835. https:// doi.org/10.1016/j.landusepol.2011.01.010

Hole DG, Perkins AJ, Wilson JD, Alexander IH, Grice PV, Evans AD (2005) Does organic farming benefit biodiversity? Biol Conserv 122:113-130. https://doi.org/10.1016/j.biocon.2004.07.018

Honkanen P, Verplanken B, Ottar S (2006) Ethical values and motives driving organic food choice. J Consum Behav 5:420-430. https:// doi.org/10.1002/cb. 190

Infante AJ, González MM (2013) The socio-ecological transition on a crop scale: the case of olive orchards in southern Spain (1750 2000). Hum Ecol 41:961-969. https://doi.org/10.1007/s10745013-9618-4

Jerez VC, García AP, Campos M, Pascual F (2014) A simple bioindication method to discriminate olive orchard management types using the soil arthropod fauna. Appl Soil Ecol 76:42-51. https://doi.org/10.1016/j.apsoil.2013.12.007

Jiménez B, Sánchez OA, Lorenzo ML, Rivas A (2014) Effect of organic cultivation of Picual and Hojiblanca olive varieties on the quality of virgin olive at four ripening stages. Eur J Lipid Sci 116:1-13. https:// doi.org/10.1002/ejlt.201400010

Kalogeras N, Valchovska S, Baourakis G, Kalaitzis P (2009) Dutch consumers' willingness to pay for organic olive oil. Int Food Agribusiness Mark 21:286-311. https://doi.org/10.1080/ 08974430802589782

Kreuger J, Peterson M, Lundgren E (1999) Agricultural inputs of pesticide residues to stream and pond sediments in a small catchment in southern Sweden. Bull Environ Contam Toxicol 62:55-62. https:// doi.org/10.1007/s001289900841

Kriwy P, Mecking RA (2012) Health and environmental consciousness, costs of behaviour and the purchase of organic food. Int J Consum Stud 36:30-37. https://doi.org/10.1111/j.1470-6431.2011.01004.x

Lal R (2009) Sequestering carbon in soils of arid ecosystems. Land Degrad Dev 20:441-454. https://doi.org/10.1002/ldr.934

Leifeld J (2012) How sustainable is organic farming? Agric Ecosyst Environ 150:121-122. https://doi.org/10.1016/j.agee.2012.01.020

Lisek J, Sas PL (2015) Biodiversity of weed communities in organic and conventional orchards. J Hortic Res 23:39-48. https://doi.org/10. 2478/johr-2015-0006
Lorenz K, Lal R (2005) The depth distribution of soil organic carbon in relation to land use and management and the potential of carbon sequestration in subsoil horizons. Adv Agron 88:35-65. https:// doi.org/10.1016/S0065-2113(05)88002-2

Mäder P, Fliebbach A, Dubois D, Gunst L, Fried P, Niggli U (2002) Soil fertility and biodiversity in organic farming. Science 296:1694 1697. https://doi.org/10.1126/science. 1071148

Maestre FT, Salguero GR, Quero JL (2012) It is getting hotter in here: determining and projecting the impacts of global environmental change on drylands. Philos Trans R Soc Biol Sci 367:3062-3075

MAGRAMA (2007) Estudio de Mercado. Observatorio del consumo y la distribución alimentaria. Monográfico productos ecológicos. http:// www.magrama.gob.es/es/alimentacion/temas/laagriculturaecologica/productos_ecologicos_tcm7-8099.pdf. Accessed 9 December 2016

MAGRAMA (2013a) Caracterización del sector de la producción ecológica española: valor, volumen y mercado y evaluación del impacto económico del comercio electrónico en la producción ecológica española. Ministerio de Agricultura, Alimentación y Medio Ambiente, Madrid

MAGRAMA (2013b) Agricultura ecológica. Estadísticas 2012. NIPO 280-13-156-4. Madrid

MAGRAMA (2015) Ministerio de Agricultura, Alimentación y Medio Ambiente. Anuario de Estadísticas. http://www.mapama.gob.es/es/ estadistica/temas/publicaciones/anuario-de-estadistica/2016/default. aspx. Accessed 27 March 2018

MAPAMA (2014) Ministerio de Agricultura, Alimentación y Medio Ambiente. Evolución de la Caracterización de la Tipología y Perfil Socio-demográfico del consumidor de Alimentos Ecológicos en España. Secretaría General Técnica. Centro de Publicaciones, Madrid

MAPAMA (2016) Datos de producción, movimientos y existencias de aceite de oliva y aceitunas de mesa. Situación del mercado del aceite de oliva. Ministerio de Agricultura, Alimentación y Medio Ambiente. http://www.mapama.gob.es/es/agricultura/temas/ producciones-agricolas/22msaproduccionybalancedeaoyama30-042016situacionmercadoaomayo2016 tcm7-422803.pdf. Accessed 15 June 2017

MEA (2005) Millennium ecosystem assessment. Summary for decision makers. Ecosystems and human well-being

Millán VTMG, Amador HL, Arjona FJM (2015) El oleoturismo: una alternativa para preservar los paisajes del olivar y promover el desarrollo rural y regional de Andalucía (España). Rev Geogr Norte Grande (60):195-214

Mohamad RS, Bteich MR, Cardone G, Marchini A (2013) Economic analysis inorganic olive farms: the case of the ancient olive trees in the rural parkland in Apulia. New Mediterr 4:55-61

Molinero EMA, Rodríguez PCR (2012) Oportunidades y barreras al emprendimiento rural. Madrid

Montarano G, Xiloyannis C, Nuzzo V, Dichio B (2017) Orchard management, soil organic carbon and ecosystem services in Mediterranean fruit tree crops. Sci Hortic 217:92-101. https://doi. org/10.1016/j.scienta.2017.01.012

Montes BM, Navas CA, Landa BB (2013) Linking microbial functional diversity of olive rhizosphere soil to management systems in commercial orchards in southern Spain. Agric Ecosyst Environ 181: 169-178. https://doi.org/10.1016/j.agee.2013.09.021

Nardino M, Pernice F, Rossi F, Georgiadis T, Facini O, Motisi A, Drago A (2013) Annual and monthly carbon balance in an intensively managed Mediterranean olive orchard. Photosynthetica 51:63-74. https://doi.org/10.1007/s11099-012-0079-6

Organic Farming in Europe (2012) Recent developments and future prospects. Foundation Ecology \& Agriculture (SOEL, Germany) and Research Institute of Organic Agriculture FIBL, Switzerland

Ottomano PG, Govindan K, Loisi RV, Dal Sasso P, Roma R (2016) Greenways for rural sustainable development: an integration 
between geographic information systems and group analytic hierarchy process. Land Use Policy 50:429-440. https://doi.org/10.1016/j. landusepol.2015.10.016

Pajares S, Gallardo JF, Masciandaro G, Ceccanti B, Etchevers JD (2011) Enzyme activity as an indicator of soil quality changes in degraded cultivated Acrisols in the Mexican trans-volcanic belt. Land Degrad Dev 22:373-381. https://doi.org/10.1002/ldr.992

Palupi E, Jayanegara A, Ploeger A, Kahl J (2012) Comparison of nutritional quality between conventional and organic dairy products: a meta-analysis. J Sci FoodAgric 92:2774-2781. https://doi.org/10. $1002 /$ jsfa.5639

Parra LC, Calatrava RJ, de Haro GT (2005) Evaluación comparativa multifuncional de sistemas agrarios mediante AHP: aplicación al olivar ecológico, integrado y convencional de Andalucía. Econ Agrar Recur Nat 5:27-55

Parras AL, Lozano GB (2014) Conventional tillage vs. organic farming in relation to soil organic carbon stock in olive groves in Mediterranean rangelands (southern Spain). Solid Earth Discuss 6:35-70. https:// doi.org/10.5194/sed-6-35-2014

Parras AL, Díaz JL, Lozano GB (2013) Organic farming affects C and N in soils under olive groves in Mediterranean areas. Land Degrad Dev 26:800-806. https://doi.org/10.1002/ldr.2231

Picchi MS, Marchi S, Albertini A, Petacchi R (2017) Organic management of olive orchards increases the predation rate of overwintering pupae of Bactroceraoleae (Diptera: Tephritidae). Biol Control 108: 9-15. https://doi.org/10.1016/j.biocontrol.2017.02.002

Preston CD, Telfer MG, Arnold HR, Carey PD, Cooper JM, Dines TD, Hill MO, Pearman DA, Roy DB, Smart SM (2002) The changing flora of the UK. DEFRA, London

Reganold JP, Elliott LF, Unger YL (1987) Long-term effects of organic and conventional farming on soil erosion. Nature 330:370-372. https://doi.org/10.1038/330370a0

Ruano F, Lozano C, García P, Peña A, Tinaut A, Pascual F, Campos M (2004) Use of arthropods for the evaluation of the olive-orchard management regimes. Agric For Entomol 6:111-120. https://doi. org/10.1111/j.1461-9555.2004.00210.x

Sánchez MJD, Paniza CA (2015) The olive monoculture in the south of Spain. European J Geography 6:16-29

Sánchez MS, Castro J, Alonso PE, Alonso PJL, García BJM, Talavera M, Durán ZVH (2015) Tillage and herbicide decrease soil biodiversity in olive orchards. Agron Sustain Dev 35:691-700. https://doi.org/ 10.1007/s13593-014-0266-x

Solomou DA, Sfougaris AI (2014) Bird community characteristics as indicators of sustainable management in olive grove ecosystems of Central Greece. J Nat Hist 49:301-325. https://doi.org/10.1080/ 00222933.2014.987839

Soriano MA, Álvarez S, Landa BB, Gómez JA (2013) Soil properties in organic olive orchards following different weed management in a rolling landscape of Andalusia, Spain. Renew Agric Food Syst 29: 83-91. https://doi.org/10.1017/S1742170512000361

van Berkel DB, Verburg PH (2014) Spatial quantification and valuation of cultural ecosystem services in an agricultural landscape. Ecol Indic 37:163-174. https://doi.org/10.1016/j.ecolind.2012.06.025

Vega-Zamora M (2013) El comportamiento del consumidor de aceite de oliva virgen extra ecológico en España. Un studio exploratorio. Agroalimentaria 19:51-60

Vega-Zamora M, Parras RM, Murgado AEM, Torres RFJ (2013) The influence of the term organic on food purchasing behaviour. Procedia Soc Behav Sci 81:660-671. https://doi.org/10.1016/j. sbspro.2013.06.493

Vicente VJL, García RR, Francaviglia R, Aguilera E, Smith P (2016) Soil carbon sequestration rates Mediterranean woody crops using recommended management practices: a meta-analysis. Agric Ecosyst Environ 235:204-214. https://doi.org/10.1016/j.agee.2016.10.024

Yeates GW, Bongers T (1999) Nematode diversity in agroecosystems. Agric Ecosyst Environ 74:113-135. https://doi.org/10.1016/ S0167-8809(99)00033-X 